\title{
Interleukin-4 -33 C/T Gene Polymorphisms are not Associated with Type 2 Diabetes Mellitus
}

\author{
Milahayati Daulay ${ }^{1 *}$, Mutiara Indah Sari ${ }^{2}$ \\ ${ }^{1}$ Department of Physiology, Faculty of Medicine, Universitas Sumatera Utara, Medan, Sumatera Utara, Indonesia; ${ }^{2}$ Department \\ of Biochemistry, Faculty of Medicine, Universitas Sumatera Utara, Medan, Sumatera Utara, Indonesia
}

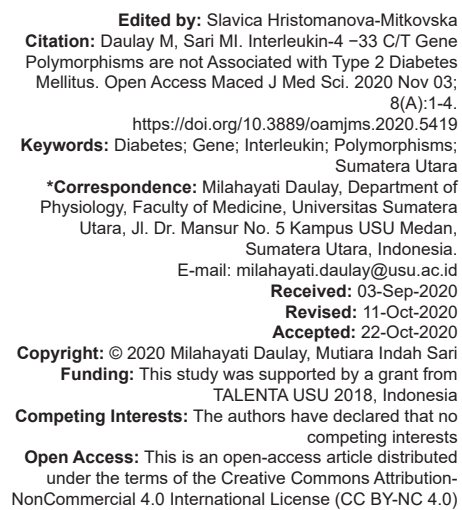

Edited by: Slavica Hristomanova-Mitkovska Citation: Daulay M, Sari MI. Interleukin-4 -33 C/T Gene Polymorphisms are not Associated with Type 2 Diabete Mellitus. Open Access Maced J Med Sci. 2020 Nov 03 8(A):1-4 https://doi.org/10.3889/oamjms.2020.541 Keywords: Diabetes; Gene; Interleukin; Polymorphisms; Sumatera Utara *Correspondence: Milahayati Daulay, Department . Utara, Jl. Dr. Mansur No. 5 Kampus USU Medan, E-mail: milahayati.daulay@usu.ac.id Received: 03-Sep-2020 Revised: 11-Oct-2020 Accepted: 22-Oct-2020
Copyright: $\odot 2020$ Milahayati Daulay, Mutiara Indah Sar Funding: This study was supported by a grant from Competing Interests: The authors have declared that Competing Interests: The authors have declared that $n$ competing interests Open Access: This is an open-access article distibuted onCommercial 4.0 International License (CC BY-NC 4.0)

\begin{abstract}
BACKGROUND: Various studies have shown variations in the interleukin-4 (IL) gene associated with type 2 diabetes mellitus (T2DM) in different populations and ethnicities.

AIM: The objective of this study was to determine the genetic variation of the IL-4 $-33 \mathrm{C} / \mathrm{T}$ gene in some T2DM patients compared with healthy control in Medan, Sumatera Utara province, Indonesia.

METHODS: DNA from T2DM patients and healthy control was isolated, then the determination of the IL-4 -33 C/T gene polymorphism was carried out using the polymerase chain reaction-restriction fragment length polymorphism technique.

RESULTS: In all samples of this study, IL-4 $-33 \mathrm{C} / \mathrm{T}$ gene polymorphisms were found in patients with T2DM and healthy control but were not statistically significant.

CONCLUSION: The IL-4 -33 C/T gene polymorphism has no relationship with the incidence of T2DM in a portion of
\end{abstract} our population in Medan, Sumatera Utara province, Indonesia.

\section{Introduction}

Based on various epidemiological studies, the prevalence of diabetes mellitus (DM) tends to increase. WHO in 1998 estimated the prevalence of DM worldwide as much as 300 million by 2025. The highest number of DM sufferers is predicted to be in the Western Pacific and Southeast Asia regions. Increasing the number of people with DM occurs in developing countries, mainly [1], [2], [3]. In developing countries, as many as $90-95 \%$ of all DM sufferers are DM type 2 groups [4]. The International Diabetes Federation estimates that people with diabetes in Indonesia increased from 10 million in 2015 to 16.2 million in 2040 [5].

DM is a group of metabolic diseases characterized by hyperglycemia as a result of a disorder in insulin secretion, insulin action, or both [6]. Type 2 diabetes is a complex disorder resulting from the interaction of genetic and environmental factors. Genetic identification in people with DM is essential to understand the pathogenesis of DM [7], [8]. Many kinds of research show that the inflammatory process plays a role in the incidence and complications of type 2 diabetes [1], [9]. Chronic hyperglycemia can increase the production of pro-inflammatory and antiinflammatory cytokines. One of the anti-inflammatory cytokines that play a role in type 2 diabetes is interleukin (IL)-4 [10]. Several studies have shown an association between IL-4 gene polymorphisms and the incidence of DM and its complications in different populations and ethnicities. This study aimed to evaluate the polymorphism of the IL-4 $-33 \mathrm{C} / \mathrm{T}$ gene in type $2 \mathrm{DM}$ (T2DM) patients compared with healthy control in our subset of resident in Medan, Sumatera Utara, Indonesia. The study is the first one to analyze the polymorphism of the IL-4 gene at this locus in people with T2DM.

\section{Methods}

The study is analytical research with a crosssectional study approach. The participants of the study were patients with T2DM who underwent outpatient care at Universitas Sumatera Utara Hospital and healthy control taken from the same place. The sampling technique used was purposive sampling. The number of research subjects was 81 subjects consisting of 40 
subjects with T2DM and 40 healthy control subjects. The ethics of this study was approved by the Health Research Ethics Committee of the Faculty of Medicine, Universitas Sumatera Utara. The research subjects signed the consent form after being given a detailed explanation and understanding of the purposes and benefits of the study before the research procedure. All participants' blood was drawn for DNA isolation, followed by gene analysis using the polymerase chain reaction-restriction fragment length polymorphism (PCR-RFLP) method.

\section{Examination of IL-4 $-33 \mathrm{C} / \mathrm{T}$ gene polymorphisms}

DNA isolation was carried out using the Wizard $^{\circledR}$ Genomic DNA Purification Kit (Promega, USA). The IL-4 -33 C/T gene PCR procedure refers to the technique used in the study of Micheal et al. [11]. The primers used, PCR products, restriction enzymes, and RFLP fragments can be seen in Table 1.

Table 1: Primer used for genotyping and genomic sequence polymorphism analysis of IL-4-33 C/T gene by RFLP

\begin{tabular}{|c|c|c|c|c|}
\hline Primer & Primer sequence & $\begin{array}{l}\text { PCR } \\
\text { product }\end{array}$ & $\begin{array}{l}\text { Restriction } \\
\text { enzyme }\end{array}$ & $\begin{array}{l}\text { RFLP } \\
\text { fragments }\end{array}$ \\
\hline rs2070874_F & CAAGTTACTGACAATCTGGTGT & 223 bp & BsmAl & $C=178,45$ \\
\hline rs2070874_R & CGGCACATGCTAGCAGGAA & & & $\begin{array}{l}T=140 \\
45,38\end{array}$ \\
\hline \multicolumn{5}{|c|}{$\begin{array}{l}\text { IL-4: Interleukin 4; RFLP: Restriction fragment length polymorphism; PCR: Polymerase chain reaction; } \\
\text { bp: Base pairs }\end{array}$} \\
\hline & he PCR compositi & & ontains & $1 \times \quad \mathrm{Taq}$ \\
\hline
\end{tabular}

Buffer, 10 pmol primer forward, 10 pmol primers reverse, $0.2 \mathrm{mM}$ dNTP, $1 \mathrm{U}$ Taq DNA polymerase, and $100 \mathrm{ng}$ genomic DNA. PCR amplification used initial denaturation at $95^{\circ} \mathrm{C}$ for $5 \mathrm{~min}$. Subsequent PCR examinations were carried out for 35 cycles in the form of denaturation $\left(95^{\circ} \mathrm{C}\right.$ for $\left.45 \mathrm{~s}\right)$, annealing $\left(58^{\circ} \mathrm{C}\right.$ for $45 \mathrm{~s})$, extensification $\left(72^{\circ} \mathrm{C}\right.$ for $\left.45 \mathrm{~s}\right)$, and final extensification $\left(72^{\circ} \mathrm{C}\right.$ for $\left.7 \mathrm{~min}\right)$. Cutting PCR products is done by giving BsmAl restriction enzymes. The cut results were examined using electrophoresis with $4 \%$ agarose.

\section{Statistical analysis}

Data were analyzed using statistical software. This study uses the Kolmogorov-Smirnov normality test to determine the normality of data distribution analytically. The Mann-Whitney test tested differences in gene polymorphisms between groups. $p<0.05$ were considered statistically significant.

\section{Results}

Analysis of the IL-4 -33 C/T gene polymorphism can be seen in Table 2, which is found in 3 alleles, CC, CT, and TT genotypes.
Table 2: Characteristics of type 2 diabetic patient and healthy control

\begin{tabular}{llll}
\hline Characteristics & Control $(\mathrm{n}=41)$ & T2DM $(\mathrm{n}=40)$ & $\mathrm{p}$ \\
\hline Sex & $20(48.7 \%)$ & $21(52.5 \%)$ & \\
Male & $21(51.3 \%)$ & $19(47.5 \%)$ & \\
Female & $46.83 \pm 11.7$ & $58.73 \pm 10.8$ & \\
Age (years) & & & \\
Gene polymorphisms & $2(4.9 \%)$ & $4(10.0 \%)$ & $>0.05$ \\
CC & $17(41.5 \%)$ & $16(40.0 \%)$ & \\
CT & $22(53.7 \%)$ & $20(50.0 \%)$ & \\
TT &
\end{tabular}

The frequency of the CC genotype was 4 $(10.0 \%)$ in the T2DM patients and $2(4.9 \%)$ in the healthy control. Our results also revealed that the frequency of the CT genotype was $16(40.0 \%)$ and $17(41.5 \%)$ in the patients and healthy control, respectively. The frequency of the TT genotype was 20 (50.0\%) in the patients and $22(53.7 \%)$ in the healthy control. A nonsignificant difference between the two groups regarding genotypes was confirmed ( $p>0.05$ ).

\section{Discussion}

IL-4 is an anti-inflammatory cytokine that plays a role in immune system regulation. Studies show that IL-4 plays a role in autoimmune and allergic diseases such as multiple sclerosis, systemic lupus erythematosus, nephrotic syndrome, graft rejection, asthma, and DM types 1 and 2. Immunologists say that IL-4 gene polymorphisms are associated with various immune system disorders, such as polymorphisms in the IL-4 promoter region (IL4 $-590 \mathrm{C} / \mathrm{T}$ ) associated with atopic dermatitis, multiple sclerosis, rheumatoid arthritis, and atopic asthma [12], [13]. The inflammatory process that is mediated by the immune system is a pathophysiological mechanism seen in diabetes and its complications [14]. DM is a complex metabolic disorder resulting from the interaction of genetic and environmental factors. Chronic hyperglycemia causes inflammation that is characterized by increased cytokine production. IL-4 is one of the anti-inflammatory cytokines associated with T2DM. IL-4 is a cytokine produced by T lymphocyte cells which have a role in the activation of $B$ cells to form antibodies [15], [16]. Several regions on chromosomes containing DM-related genes have been identified and several genes have been recognized for their role [17].

This study generally aims to explain the description of genetic polymorphism as a risk factor for T2DM. In this study, there was an IL-4 -33 C/T gene polymorphism in patients with T2DM and healthy control, but the difference was not significant. Our findings are the first study to examine the polymorphism of the IL-4 gene at this locus. Previous studies examined the IL-4 gene polymorphism at different loci with different results. Research conducted by Arababadi in Iran found no significant differences in the polymorphism of the IL-4 gene in the -590 region in 
people with T2DM compared with healthy control [18]. Završnik also found no significant difference in the IL-4 $-590 \mathrm{C} / \mathrm{T}$ gene polymorphism in T2DM patients with nephropathy in Slovenia [19]. However, in Egypt, Alsaid found a significant difference in the IL-4 -590 C/T gene polymorphisms between T2DM patients compared with healthy control [20]. This shows that the IL-4 $-590 \mathrm{C} / \mathrm{T}$ gene polymorphism is a risk factor for T2DM in the population in Egypt. The same thing was also found in the study of Arababadi in Iran. In this study, there were significant differences between $\mathrm{C} / \mathrm{C}, \mathrm{T} / \mathrm{C}$, and $T / T$ genotypes in T2DM patients with nephropathy compared to healthy control [21]. This means that functionally, the IL-4 gene polymorphism plays an important role in the pathogenesis of complications of diabetic nephropathy in T2DM patients. In line with the research previously mentioned, another study found a significant difference in the IL-4 $-590 \mathrm{C} / \mathrm{T}$ gene polymorphisms in T2DM patients with chronic kidney disease compared with those without chronic kidney disease and healthy subjects in India [2]. Meanwhile, in Taiwan, polymorphism of the IL-4 $-589 \mathrm{C} / \mathrm{T}$ and $-34 \mathrm{C} / \mathrm{T}$ genotypes differed significantly between T2DM patients and control subjects [22]. The differences in these studies indicate that unique genetic characteristics and possibly different etiological or environmental factors may be involved in the pathogenesis of T2DM.

In general, we did not find an association between IL-4 -33 C/T gene polymorphisms in T2DM patients, in Medan, Sumatera Utara, Indonesia. This denotes that IL-4 may not be a risk factor for T2DM patients in this population. However, taking into account the limitations of the study, particularly related to the relatively small sample size, we suggest a wider study with a higher number of cases and controls. Further research in different communities in Indonesia can strengthen the results of this study. We also recommend more extensive research by analyzing blood levels of cytokines and considering diabetes complications that occur in T2DM patients.

\section{Acknowledgment}

The authors are thankful to the Ministry of Research and Technology and Higher Education of the Republic of Indonesia. This work was supported by research grants from TALENTA USU 2018 contract number 2590/UN5.1.R/PPM/2018 date 16 March 2018.

\section{References}

1. Sari MI, Daulay M, Widyawati T, Anggraini DR, Wahyuni DD, Syarifah $S$. The tumor necrosis factor- $\alpha$ gene polymorphism $(-308 \mathrm{G} / \mathrm{A})$ in Type 2 diabetes mellitus patients with tuberculosis infection. In: Proceedings of the $3^{\text {rd }}$ International Conference on Mathematics, Science, Education and Engineering, Padang, Indonesia. United Kingdom: Institute of Physics Publishing; 2018. p. 1-6.

2. Neelofar K, Ahmad J, Ahmad A, Alam K. Study of IL4-590C/T and IL6-174G/C gene polymorphisms in Type 2 diabetic patients with chronic kidney disease in North Indian population. J Cell Biochem. 2017;118:1803-9. https://doi.org/10.1002/jcb.25853 PMid:27996163

3. Jinpon $P$, Jaroensutasinee $M$, Jaroensutasinee $K$. Risk assessment of Type 2 diabetes mellitus in the population of Chonburi, Thailand. Walailak J Sci Tech. 2017;14:25-33.

4. World Health Organization. Global Report on Diabetes. Paris: World Health Organization; 2016. p. 1-86.

5. International Diabetes Federation. Diabetes Atlas. $7^{\text {th }}$ ed Brussels, Belgium: International Diabetes Federation; 2015. p. 1-142.

6. American Diabetes Association. Diagnosis and classification of diabetes mellitus. Diabetes Care. 2014;37:S81-90. https://doi.org/10.2337/dc14-s081 PMid:24357215

7. Politi C, Ciccacci C, D'Amato C, Novelli G, Borgiani P, Spallone V. Recent advances in exploring the genetic susceptibility to diabetic neuropathy. Diabetes Res Clin Pract. 2016;120:198-208. https://doi.org/10.1016/j.diabres.2016.08.006 PMid:27596057

8. Saxena M, Srivastava N, Banerjee M. Cytokine gene variants as predictorsofType2diabetesmellitus.CurrDiabetesRev.2018;14:30719. https://doi.org/10.2174/1573399813666170112145429 PMid:28081697

9. Abd Elneam Al, Mansour NM, Zaki NA, Taher MA. Serum interleukin-18 and its gene haplotypes profile as predictors in patients with diabetic nephropathy. Open Access Maced J Med Sci. 2016;4:324-8. https://doi.org/10.3889/oamjms.2016.074 PMid:27703550

10. Sheikhpour R. Diabetes and oxidative stress: The mechanism and action. Iran J Diabetes Obes. 2013;5:40-5.

11. Micheal $S$, Minhas $K$, Ishaque $M$, Ahmed $F$, Ahmed $A$. IL-4 gene polymorphisms and their association with atopic asthma and allergic rhinitis in Pakistani patients. J Investig Allergol Clin Immunol. 2013;23:107-11. PMid:23654077

12. Liang J, Liu $Y$, Xue R, Chen L, Chen H, Shao L, et al. Interleukin 4-590C/T (rs2243250) polymorphism is associated with increased risk of atopic dermatitis: Metaanalysis of case-control studies. Dermatitis. 2017;28:14451. https://doi.org/10.1097/der.0000000000000265 PMid:28169853

13. Qiu LJ, Ni J, Cen $\mathrm{H}$, Wen PF, Zhang $\mathrm{M}$, Liang $\mathrm{Y}$, et al. Relationship between the IL-4 gene promoter-590C/T (rs2243250) polymorphism and susceptibility to autoimmune diseases: A meta-analysis. J Eur Acad Dermatol Venereol. 2015;29:48-55. PMid:24628947

14. Navarro-González JF, Mora-Fernández C. The role of inflammatory cytokines in diabeticnephropathy. JAmSocNephrol. 2008;19:433-42. https://doi.org/10.1681/asn.2007091048 PMid: 18256353

15. Voehringer D, Reese TA, Huang X, Shinkai K, Locksley RM. Type 2 immunity is controlled by IL-4/IL-13 expression in hematopoietic non-eosinophil cells of the innate immune system. J Exp Med. 2006;203:1435-46. https://doi.org/10.1084/jem.20052448 PMid: 16702603

16. Francés DE, Ingaramo PI, Ronco MT, Carnovale CE. Diabetes, an inflammatory process: Oxidative stress and TNF-alpha involved in hepatic complication. J Biomed Sci Eng. 2013;6:64553. https://doi.org/10.4236/jbise.2013.66079 
17. Banerjee M, Saxena M. Genetic polymorphisms of cytokine genes in Type 2 diabetes mellitus. World $\mathrm{J}$ Diabetes. 2014;5:493-504 PMid:25126395

18. Arababadi MK, Pourfathollah AA, Daneshmandi $S$ Hassanshahi G, Zrandi ER, Shamsizadeh A, et al. Evaluation of relation between IL-4 and IFN- $\gamma$ polymorphisms and Type 2 Diabetes. Iran J Basic Med Sci. 2009;12:100-4.

19. Završnik M, Letonja J, Makuc J, Šeruga M, Cilenšek I, Petrovič D. Interleukin-4 (IL4)-590C/T (rs2243250) gene polymorphism is not associated with diabetic nephropathy (DN) in Caucasians with Type 2 diabetes mellitus (T2DM). Bosn J Basic Med Sci. 2018;18:347-51. https://doi.org/10.17305/bjbms.2018.2688
20. Alsaid A, El-Missiry M, Hatata ES, Tarabay M, SettinA. Association of IL-4-590 C>T and IL-13-1112 C>T gene polymorphisms with the susceptibility to Type 2 diabetes mellitus. Dis Markers. 2013;35:243-7. https://doi.org/10.1155/2013/107470 PMid:24167373

21. Arababadi MK. Interleukin-4 gene polymorphisms in Type 2 diabeticpatientswithnephropathy. Iran JKidneyDis. 2010;4:302-6. PMid:20852371

22. Ho KT, Shiau MY, Chang YH, Chen CM, Yang SC, Huang CN. Association of interleukin-4 promoter polymorphisms in Taiwanese patients with Type 2 diabetes mellitus. Metabolism. 2010;59:1717-22. https://doi.org/10.1016/j.metabol.2010.04.010 PMid:20580039 